\title{
C.A. Базарова
}

\section{ИЗМЕНЕНИЯ СОСТОЯНИЯ ЭНДОТЕЛИАЛЬНОЙ СИСТЕМЫ У БОЛЬНЫХ БРОНХИАЛЬНОЙ АСТМОЙ ПРИ ВКЛЮЧЕНИИ В КОМПЛЕКСНУЮ ТЕРАПИЮ ПРЕПАРАТА L-АРГИНИН}

Республиканский специализированный научно-практический медицинский центр терапии и медицинской реабилитации, г. Ташкент, Узбекистан

\begin{abstract}
Резюме. Целью исследования было изучить влияние L-аргинина на показатели эндотелиальной системы у больных бронхиальной астмой. Обследовано 82 пациента с легким и со среднетяжелым персистирующим течением бронхиальной астмы (БА). Были сформированы две группы. Больные основной группы в дополнение к стандартной базисной терапии получали донатор оксида азота - L-аргинин. Группа сравнения получала только базисную терапию. Состояние эндотелиальной
\end{abstract}

Введение. Бронхиальная астма (БА), являясь тяжелым хроническим заболеванием дыхательных путей, представляет собой серьезную проблему для здравоохранения [1].

Значительный прогресс достигнут в отношении понимания патогенетических механизмов БА. За последние годы разработаны и внедрены национальные программы по борьбе с астмой.

В настоящее время в качестве системных проявлений БА рассматриваются кардиоваскулярные эффекты, среди которых, как первичное звено поражения стенки сосуда, фигурирует эндотелиальная дисфункция $[2,6]$. Именно дисфункция эндотелия, обнаруживаясь уже на ранних стадиях заболевания, усугубляет нарастающие дыхательную недостаточность, гипоксемию и гипоксию тканей $[8,14]$. За последние годы получены новые данные о роли нарушений функциональной активности эндотелия в патогенезе бронхолегочных заболеваний $[11,3]$. Объективная оценка состояния эндотелия сосудов важна не только для определения степени его дисфункции, подбора патогенетически обоснованного лекарственного и немедикаментозного лечения, но и для прогнозирования течения заболевания [12, 10]. Несмотря на появление новых классов лекарственных препаратов для лечения БА, сохраняется значительное количество больных тяжелыми формами этого заболевания, нуждающихся в длительном приеме препаратов базисного лечения, которые, как было установлено в последние годы, обладают повреждающим действием на сосудистую стенку $[9,13]$. Влияние современных медикаментозных средств на функциональное состояние эндотелия сосудов у больных БА малоизучено.

Широкий диапазон выполняемых функций некоторых эндотелиальных факторов предполагает непосредственное участие этих веществ в патофизиологических механизмах БА [4, 7]. В формировании функциональных и структурных нарушений при БА неоднозначная роль отводит- системы оценивали до и после десятидневного курса лечения по показателям: изменения уровня основных стабильных метаболитов оксида в плазме крови и в конденсате выдыхаемого воздуха, а также уровня Lаргинина в плазме крови.

Ключевые слова: L-аргинин, эндотелиальная дисфункция, оксид азота, бронхиальная астма.

ся оксиду азота (NO), продуцируемому различными формами NO-синтаз (NOS). Показано, что в физиологических условиях пикомолярные количества NO, синтезируемого конститутивной NOS, оказывают бронходилатирующее, противовоспалительное и антипролиферативное действия, в то время как в условиях воспаления сверхсинтез NO индуцибельной изоформой фермента приводит к противоположному эффекту [5, 8]. Разработка способов медикаментозной коррекции эндотелиальной дисфункции у больных БА представляется актуальной.

Цель исследования. Изучить изменения состояния эндотелиальной системы у больных БА при включении в комплексную терапию препарата L-аргинина.

Материал и методы. Обследовано 82 пациента с легким и со среднетяжелым персистирующим течением БА в возрасте от 18 до 55 лет $(38,5$ $\pm 4,2$ лет), с длительностью заболевания более 12 лет (в среднем $16 \pm 4,5$ лет). Методом случайной выборки были сформированы две группы. Больные основной группы (n=42), в дополнение к стандартной базисной терапии (GINA, 2007) получали донатор оксида азота - L-аргинин. Препарат (100 мл 4,2 \% раствора, Тивортин, ЮРіЯФАРМ, Украина) вводили в/в капельно, 1 раз в сутки, в течение 10 дней. Группа сравнения $(\mathrm{n}=40)$ получали только базисную терапию. В качестве контроля обследованы 20 здоровых добровольцев. Состояние эндотелиальной системы оценивали до и после десятидневного курса лечения по показателям: изменения уровня основных стабильных метаболитов оксида азота (NO2 и NO3), которые определяли с использованием реактива Грисса (П.П. Голиков и соавт., 2004) в плазме крови и в конденсате выдыхаемого воздуха (КВВ). Сбор КВВ проводился методом Г. И. Сидоренко и др. (1980), модифицированного нами. Определение уровня L-аргинина в плазме осуществлялось методом тонкослойной ионообменной хроматографии с последующей денситометрией 
[15]. Полученные данные обработаны на персональном компьютере, в программной среде Мicrosoft Excel c использованием встроенного "Пакета анализа", специально предназначенного для решения статистических задач.

Результаты исследования и их обсуждение. Исходные данные показали, что в обеих группах пациентов содержание стабильных метаболитов оксида азота было достоверно ниже нормальных показателей в крови и в КВВ (рис.1, p<0,01), а также уровень L-аргинина в плазме был достоверно снижен (рис.2, $<<0,01)$.
После проведенного десятидневного курса лечения показатели эндотелиальной системы изменились. При этом в основной группе пациентов уровень L-аргинина достоверно поднялся $(156,74 \pm 4,25$ мкмоль/л, $p<0,01)$, и почти дошёл до нормы, уровень нитрат-ионов в крови $(12,18 \pm 0,42$ ммоль/л, р <0,01) и в КВВ $(4,51 \pm 0,19$ ммоль/л, $\mathrm{p}<0,01)$ также достоверно увеличился, но не дошёл до нормы. В группе сравнения изменения исходных показателей были незначимы и носили не достоверный характер (рис. 1, рис. 2).

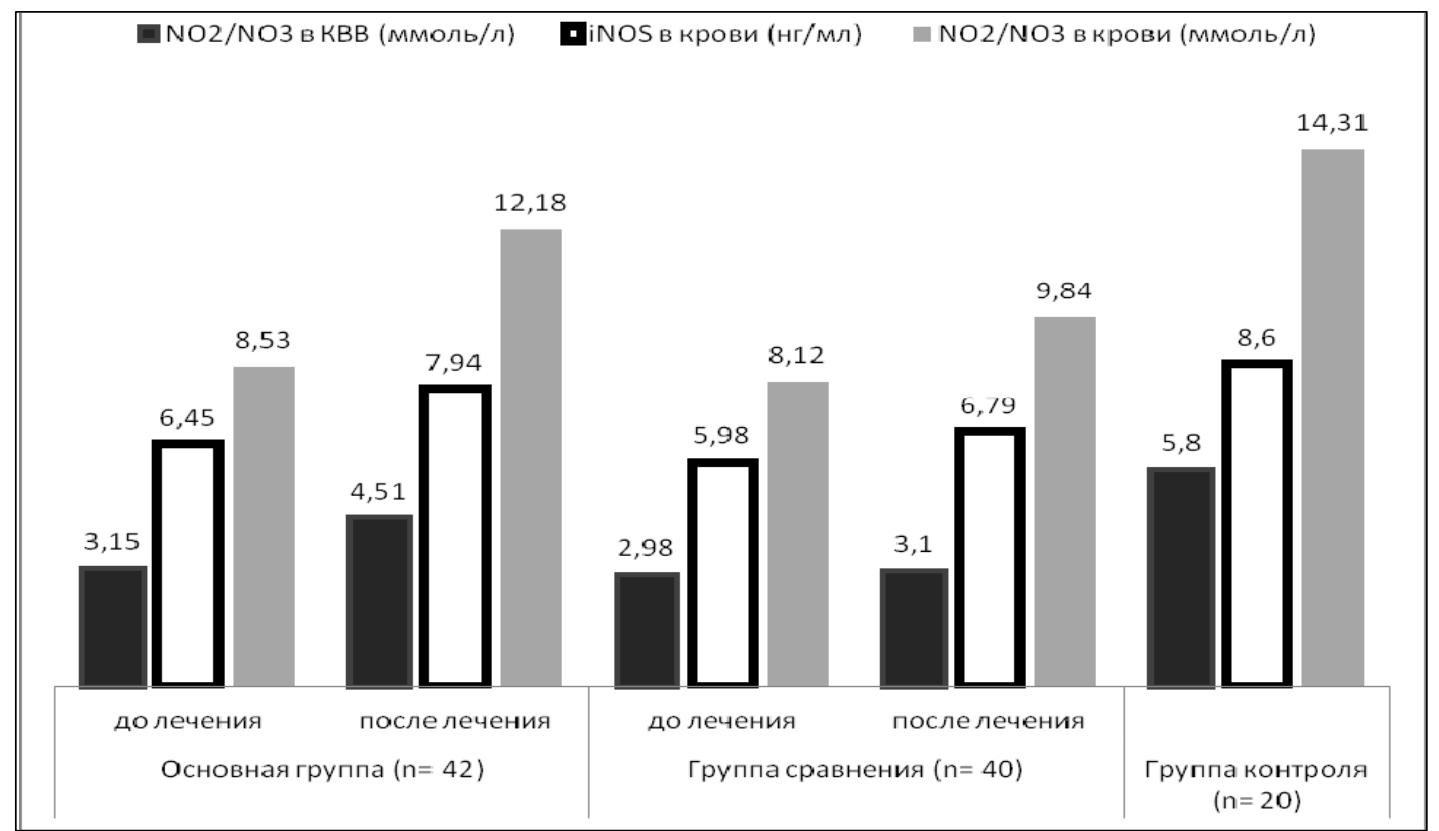

Рис. 1. Показатели эндотелиальной функции больных БА на фоне лечения

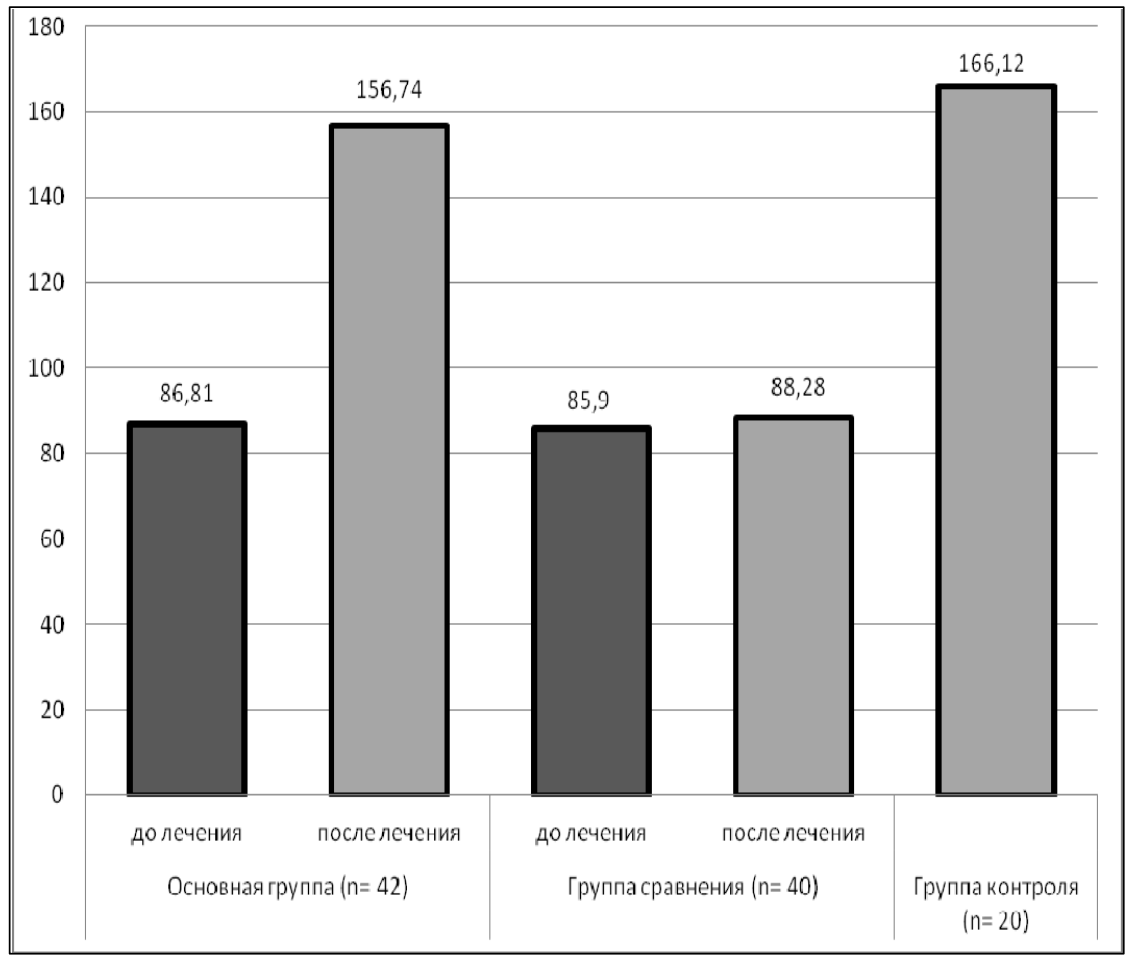

Рис. 2. Значения L-аргинина в плазме крови больных БА на фоне лечения 


\section{Вывод}

При длительном течении бронхиальной астмы (в среднем $16 \pm 4,5$ лет) легкой и среднетяжелой степени тяжести, персистирующего течения формируется эндотелиальная дисфункция со снижением уровня L-аргинина в плазме и снижением нитрат-ионов в крови и в конденсате выдыхаемого воздуха. При применении препарата Lаргинина на фоне патогенетической терапии, отмечается улучшение состояния эндотелиальной системы, которая проявляется нормализацией содержания L-аргинина в плазме и снижением нитрат-ионов как в крови, так и в конденсате выдыхаемого воздуха в короткие сроки.

\section{Литература}

1. Чучалин А.Г. Бронхиальная астма / А.Г. Чучалин. М.: Русский врач, 2001. - 144 с.

2. Борута С.А. Роль дисфункции эндотелия в формировании легочной гипертензии у больных бронхиальной астмой / С.А. Борута, Е.Р. Шахнис, М.Г. Омельяненко // Пульмонология. - 2008. - № 2. - С. 38-41.

3. Бродская Т.А. Дисфункция эндотелия и болезни органов дыхания / Т.А. Бродская, В.А. Невзорова, Б.И. Гельцер // Терапевт. архив. - 2007. - № 3. - С. 76-84.

4. Уровень плазменного эндотелина-1 и эндотелийзависимая вазодилатация при бронхиальной астме / Л.П. Воронина, Т.А. Уклистая, Е.А. Уклистая [и др.] // Кардиоваскулярная терапия и профилактика. -2009 . T. 8, № S. - C. 66a-66.

5. Глобальная стратегия лечения и профилактики бронхиальной астмы (GINA) / Перевод с англ. Пересмотр 2006г. - М.: Атмосфера, 2007. - 106c.

6. Кароли Н.А. Особенности функционального состояния эндотелия у больных бронхиальной астмой в зависимос- ти от типов циркадного ритма артериального давления / Н.А. Кароли, А.А. Рощина, А.П. Ребров // Артериал. гипертензия. - 2010. - Т. 16, № 4. - С. 390-394.

7. Benson R.C. Arginase and arginine dysregulation in asthma / R.C. Benson, K.A. Hardy, C.R. Morris // J. Allergy (Cairo). - 2011. - № 736319. Epub 2011 Apr 26.

8. Arginine kinase from the cellar spider (Holocnemus pluchei): a new asthma-causing allergen / I. Bobolea, P. Barranco, C. Pastor-Vargas [et al.] // Int. Arch. Allergy Immunol. - 2011. - Vol. 155 (2). - P. 180-186.

9. L-arginine reverses cigarette-induced reduction of fractional exhaled nitric oxide in asthmatic smokers / C.T. Bruce, D. Zhao, D.H. Yates [et al.] // Inflammopharmacology. - 2010. - Vol. 18 (1). - P. 9-16.

10. Gaston B. The biochemistry of asthma / B. Gaston // Biochim. Biophys. Acta. - 2011. - Vol. 1810 (11). P. 1017-1024.

11. Ghosh S. Nitric oxide metabolism in asthma pathophysiology / S. Ghosh, S.C. Erzurum // Biochim. Biophys. Acta. - 2011. - Vol. 1810 (11). - P. 1008-1016.

12. Beneficial effects of high dose of L-arginine on airway hyperresponsiveness and airway inflammation in a murine model of asthma / U. Mabalirajan, T. Ahmad, G.D. Leishangthem [et al.] // J. Allergy Clin. Immunol. 2010. - Vol. 125 (3). - P. 626-635.

13. Munder M. Role of arginase in asthma: potential clinical applications / M. Munder // Expert Rev. Clin. Pharmacol. 2010. - Vol. 3 (1). - P. 17-23.

14. Simvastatin inhibits goblet cell hyperplasia and lung arginase in a mouse model of allergic asthma: a novel treatment for airway remodeling? / A.A. Zeki, J.M. Bratt, M. Rabowsky [et al.] // Transl. Res. - 2010. - Vol. 156 (6). - P. 335-349.

15. Методы разделения и анализа в биохимии / Г.А. Яровая, В.Л. Доценко, Н.Н. Заболоцкий [и др.]. - М., 1992. - C. 24-27.

\section{БРОНХИАЛ АСТМАЛИ БЕМОРЛАР КОМПЛЕКС ДАВОСИГА L-АРГИНИН КУШИЛГАНДА ЭНДОТЕЛИАЛ ТИЗИМ ХОЛАТИНИ УЗГАРИШИ}

\section{С.A. Базарова}

Резюме. Текширув максади бронхиал астмага чалинган беморларда L-аргининни эндотелиал тизим холатига таъсирини урганиш эди. Енгил ва урта огир персистирловчи бронхиал астмали 82 бемор текширилган. Беморлар икки гурухга ажратилган. Асосий гурух беморларига базис даво билан бирга азот оксиди донатори - L-аргинин буюрилган. Солиштириш гурухи факат базис даво олганлар. Эндотелиал тизим холатини даводан олдин ва ун кунлик даводан сунг куйидаги курсатгичлар буйича бахолашган: азот оксидини тургун метаболитларини конда ва чикарилаетган нафас конденсатидаги курсатгичлари ва L-аргининни кондаги курсатгичи буйича.

Калит сузлар: L-аргинин, эндотелиал дисфункция, азот оксиди, бронхиал астма.

Республика ихтисослаштирилган терапия ва тиббий реабилитация илмий - амалий тиббиёт маркази, Узбекистон, Тошкент

\section{ЗМІНИ СТАНУ ЕНДОТЕЛІАЛЬНОЇ СИСТЕМИ У ХВОРИХ НА БРОНХІАЛЬНУ АСТМУ ПРИ ВКЛЮЧЕННІ ДО КОМПЛЕКСНОЇ ТЕРАПІЇ ПРЕПАРАТУ L-АРГІНІН}

\section{С.A. Базарова}

Резюме. Метою дослідження було вивчити вплив L-аргініну на показники ендотеліальної системи у хворих на бронхіальну астму. Обстежено 82 пацієнти з легким та зі середньотяжким персистувальним перебігом БА. Були сформовані дві групи. Пацієнти основної групи в доповнення до стандартної базисної терапії отримували донатор оксиду азоту - L-аргінін. Група порівняння отримувала тільки базисну терапію. Стан ендотеліальної системи оцінювали до і після десятиденного курсу лікування за показниками: зміни рівня основних стабільних метаболітів оксиду в плазмі крові і в конденсаті видихуваного повітря, а також рівня L-аргініну в плазмі крові.

Ключові слова: L-аргінін, ендотеліальна дисфункція, оксид азоту, бронхіальна астма.

Республиканський спеціалізований науково-практичний медичний центр терапії і медичної реабілітації, м. Ташкент, Узбекистан 


\section{CHANGES IN ENDOTHELIAL SYSTEM CONDITION IN PATIENTS WITH BRONCHIAL ASTHMA AFTER USING THE PREPARATION L-ARGININ IN A COMPLEX THERAPY}

\section{S.A. Bazarova}

Abstract. Research objective was to study influence of L-arginin on endothelial system indexes in patients with bronchial asthma. 82 patients with bronchial asthma have been examined. 2 groups have been formed. Patients of the basic group in addition to standard basic therapy received the nitrogen oxide donator - L-arginin. The comparison group only received a basic therapy. The condition of endothelial system was estimated before and after ten-day course of treatment based on the following indicators: changes in the level of the main stable metabolites of nitrogen oxide in plasma of blood and in a condensate of exhaled air as well as that of L-arginin in plasma.

Key words: L-arginin, endothelial dysfunction, nitrogen oxide, bronchial asthma.

Republican specialized scientifically - practical medical center of therapy and medical rehabilitation (Uzbekistan, Tashkent)

Рецензент - проф. Л.Д. Тодоріко

Buk. Med. Herald. - 2014. - Vol. 18, № 3 (71). - P. 14-17

Надійшла до редакції 24.04.2014 року

(C) С.А. Базарова, 2014 